\title{
FAKTOR YANG MEMPENGARUHI TINGKAT PENDAPATAN PETANI SAYURAN DI KABUPATEN KARO SUMATERA UTARA
}

\author{
JUNITA LUBIS \\ Dosen Tetap Sekolah Tinggi Ilmu Ekonomi (STIE) Labuhanbatu
}

\begin{abstract}
ABSTRAK
Penelitian ini bertujuan untuk pertama mengetahui faktor faktor yang mempengaruhi tingkat pendapatan, kedua untuk mengetahui tingkat keuntungan usaha tani sayuran, ketiga untuk mengetahui apakah usaha tani tersebut layak untuk dijalankan. Penelitian dengan metode proportionated stratified random sampling. Data dianalisis dengan regresi linier berganda dan analisis R/C . Hasil penelitian menunjukkan bahwa secara simultan faktor - faktor yang mempengaruhi pendapatan usahatani sayuran berpengaruh nyata terhadap pendapatan pada tingkat kepercayaan $90 \%$. Secara parsial, biaya pupuk, biaya pestisida, dan harga sayuran berpengaruh nyata terhadap pendapatan, sedangkan biaya tenaga kerja, tingkat pendidikan tidak berpengaruh nyata terhadap pendapatan. Kontribusi pendapatan petani sayuran terhadap total pendapatan keluarga petani sebesar $80,72 \%$. Nilai R/C diperoleh sebesar 2,54 yang artinya bahwa usahatani sayuran tersebut layak dilaksanakan secara finansial.
\end{abstract}

Kata kunci: sayuran, faktor pendapatan, usahatani,

\section{Latar Belakang Permasalahan}

Indonesia merupakan salah satu negara yang berkembang dengan sektor pertanian sebagai sumber mata pencaharian dari mayoritas penduduknya. Husodo (2004) mengatakan sebagian besar penduduk Indonesia menggantungkan hidupnya di sektor pertanian. Dimana penggunaan lahan di wilayah Indonesia sebagian besar diperuntukkan sebagai lahan pertanian.

Di Indonesia pembangunan agribisnis hortikultura pada berbagai sentra produksi sebagian besar telah difasilitasi melalui berbagai program dan kegiatan baik dengan dukungan APBN, APBD, maupun dukungan dana masyarakat sendiri, baik petani maupun swasta. Kegiatan dan pendanaan pembangunan hortikultura telah dilakukan untuk pengembangan budidaya dan penerapan teknologi, pemberdayaan kelembagaan petani, penguatan modal usaha. Dengan pelaksanaan program telah terjadi peningkatan produksi dan daya saing produk hortikultura serta peningkatan ketersediaan. Peningkatan produksi holtikultura ini diarahkan untuk memenuhi kebutuhan dalam negeri baik untuk konsumsi maupun bahan baku industri, peningkatan ekspor dan substitusi impor.

Sayur-sayuran tidak asing lagi bagi masyarakat, karena dalam kehidupan sehari-hari selalu hadir tanpa mengenal musim. sayuran memiliki kandungan gizi yang banyak diperlukan oleh tubuh. terutama vitamin dan mineral. Sayuran ini sangat dianjurkan untuk di konsumsi dalam menu makanan seharihari guna mencukupi kebutuhan vitamin dan mineral yang sesuai. Daerah produsen sayuran terbesar di sumatera utara adalah kabupaten karo.

Sektor pertanian merupakan sektor yang paling besar dalam memberi kesempatan kerja bagi pendududuk setempat. Sayuran sebagai komoditas pertanian dan pemenuhan kebutuhan sayuran dari bahan pangan dari tahun ketahun laju produksinya selalu meningkat. ini berarti usahatani sayuran perlu dikembangkan lebih luas lagi. Kabupaten karo merupakan daerah yang paling banyak mengusahakan usahatani sayuran. sebagai mata pencahariannya. Usahatani yang dijalankan petani sesuai dengan faktor-faktor produksi yang ada, dengan harapan akan memperoleh pendapatan yang menguntungkan bagi keluarganya. 


\section{PERUMUSAN MASALAH}

1. Apakah usahatani sayuran mempengaruhi tingkat pendapatan petani?

2. Berapa besar kontribusi pendapatan petani sayuran terhadap total pendapatan keluarga petani ?

3. Apakah usahatani sayuran di daerah penelitian layak dilaksanakan secara finansial ?

\section{Tujuan Penelitian}

Tujuan penelitian adalah untuk menganalisis :

1. Usahatani sayuran mempengaruhi tingkat pendapatan petani sayuran.

2. Total kontribusi pendapatan petani sayuran terhadap pendapatan total keluarga petani.

3. Kelayakan usahatani sayuran.

\section{Manfaat Penelitian}

Adapun manfaat penelitian ini adalah :

1. Sebagai masukan kepada para petani sayuran yang ada di Kabupaten karo dalam usaha meningkatkan tingkat pendapatannya.

2. Sebagai bahan informasi bagi pemerintah, instansi/lembaga yang terkait dalam menentukan kebijaksanaan dan dalam usaha meningkatkan pendapatan petani sayuran.

3. Sebagai informasi kepada peneliti lain untuk dapat dipergunakan sebagai referensi pada penelitian yang sejenis.

\section{Pengertian pendapatan}

Pendapatan usaha tani menurut Hastuti (2007:106) merupakan selisih antara penerimaan dan semua biaya, atau dengan kata lain pendapatan meliputi pendapatan kotor atau penerimaan total dan pendapatan bersih. Pendapatan kotor atau penerimaan total adalah adalah nilai produksi komoditas pertanian secara keseluruhan sebelum dikurangi biaya produksi.

Secara umum pendapatan merupakan tujuan utama suatu perusahaan atau usaha yang didirikan. Pendapatan juga menjadi hal yang mendasari seseorang melakukan pekerjaan. hal ini menandakan bahwa suatu usaha memang layak untuk dipertahankan karena bisa menghasilkan pendapatan bagi kehidupan pekerjanya. pendapatan juga bisa dijadikan bahan pertimbangan bagi suatu usaha, apakah usaha yang dijalankan termaksud dalam skala untung atau rugi. pendapatan dikatakan stabil bagi perekonomian seseorang apabila jumlahnya lebih besar dari pengeluaran harian orang tersebut.

Salah satu indikator utama ekonomi untuk mengukur kemampuan ekonomi masyarakat adalah tingkat pendapatan masyarakat. Indikator yang dimaksud hanya bersangkutan dengan pendapatan dan pengeluaran, akan tetapi yang lebih penting adalah mengetahui besarnya perbandingan antara penerimaan dengan pengeluaran. Pendapatan terdiri dari beberapa jenis, yaitu sebagai berikut, Pendapatan bersih (disposable income) adalah pendapatan seseorang sesudah dikurangi pajak langsung, Pendapatan diterima di muka (unearned revenues) adalah uang muka untuk pendapatan yang belum dihasilkan, Pendapatan lain-lain adalah pendapatan yang berasal dari sumber-sumber di luar kegiatan utama perusahaan, tidak termaksud dalam pendapatan operasi, misalnya : pendapatan bunga, pendapatan sewa, pendapatan dividen dan laba penjualan aktiva tetaP, Pendapatan permanen (permanent income) adalah pendapatan rata- 
rata yang diharapkan rumah tangga konsumsi selama hidupnya, Pendapatan uang (money income) adalah pendapatan rumah tangga konsumsi atau rumah tangga produksi dalam bentuk suatu kesatuan moneter, Pendapatan usaha (operating revenue) adalah pendapatan yang berasal dari kegiatan utama perusahaan.

\section{Faktor - faktor yang mempengaruhi pendapatan petani sayuran \\ 1. Produksi pertanian}

Menurut Sukirno (2003 :193) secara umum konsep produksi digunakan sebagai pendekatan terhadap aktivitas dalam proses produksi yang menjelaskan hubungan antar faktor - faktor produksi (input) dengan proses produksi itu sendiri (output).

Sedangkan menurut Suratiyah (dalam, Suzana, 2007: 65) jika permintaan akan produksi tinggi maka harga ditingkat petani akan tinggi pula sehingga dengan biaya yang sama petani akan memperoleh pendapatan yang lebih tinggi. Sebaliknya jika petani telah berhasil meningkatkan produksi tetapi harga turun maka pendapatan petani akan turun pula.

\section{Harga sayuran}

Menurut Sukirno (dalam Alwi, 2009:25) harga adalah suatu jumlah yang dibayarkan sebagai pengganti kepuasan yang sedang atau akan dinikmati dari suatu barang atau jasa yang diperjualbelikan. Harga merupakan perjanjian moneter terakhir yang menjadi nilai dari pada suatu barang atau jasa, sedangkan harga menurut Kadariah (dalam Alwi, 2009:25) adalah tingkat kemampuan suatu barang atau jasa untuk ditukarkan dengan barang lain, harga ditentukan oleh dua kekuatan yaitu permintaan dan penawaran yang saling berjumpa dalam pasar (tiap organisasi tempatpenjual dan pembeli suatu benda dipertemukan).

\section{Tingkat pendidikan}

Pendidikan yang didapat seseorang akan mengembangkan dan meningkatkan kemampuannya. Seseorang dengan tingkat pendidikan yang lebih tinggi memungkinkan dirinya untuk bekerja lebih produktif dibandingkan dengan yang berpendidikan rendah. Hal ini disebabkan karena tenaga kerja mempunyai pendidikan tinggi akan mempunyai wawasan, pengalaman dan kematangan dalam berfikir dalam bekerja lebih baik (Melati,2008:40)

Menurut Yusuf dalam Suzana (2007:11) tingkat pendidikan seseorang akan mempengaruhi seseorang dalam mencapai keberhasilan, maka semakin tinggi pendidikan seseorang maka akan tinggi pula keberhasilannya dalam menyelesaikan tugasnya. Begitu juga sebaliknya jika semakin rendah tingkat pendidikan seseorang maka akan rendah pula keberhasilannya dalam menyelesaikan tugasnya.

\section{Biaya usaha Tani}

Menurut Sadono Sukirno (2006:208) biaya produksi adalah semua pengeluaran yang dilakukan oleh perusahaan untuk memperoleh faktor - faktor produksi dan bahan - bahan mentah yang akan untuk menciptakan barang - barang yang diproduksikan perusahaan tersebut.

Menurut Suherman Rosyidi dalam buku Pendekatan Kepada Teori Ekonomi Mikro dan Makro (2009) biaya produksi adalah biaya yang harus dikeluarkan oleh pengusaha untuk dapat menghasilkan output, seorang pengusaha yang ingin melakukan produksi tentu harus terlebih menyediakan faktor - faktor produksi itu.

1. Jenis bibit

Menurut Hastuti (2007: 39) bibit menentukan keunggulan dari suatu komoditas. Bibit yang unggul biasanya tahan terhadap penyakit, hasil komoditasnya berkualitas tinggi dibandingkan dengan komoditas lain sehingga harganya dapat bersaing di pasar. 
Penggunaan bibit unggul dapat meningkatkan produksi perhektar sekaligus meningkatkan produksi total, oleh karena itu bibit unggul perlu disebar kepada petani yang bersangkutan melalui penyuluhan atau penyampaian informasi yang tepat serta memberikan kemudahan kepada petani untuk memperoleh bibit unggul sehingga dengan penggunaan bibit unggul tersebut dapat ditingkatkan produksi secara keseluruhan sesuai dengan apa yang diharapkan.

\section{Hipotesis}

1. Usahatani sayuran berpengaruh positif terhadap pendapatan petani sayuran di lokasi penelitian.

2. Pendapatan petani sayuran memberi kontribusi terhadap total pendapatan keluarga petani.

3. Usaha tani sayuran di lokasi penelitian layak untuk dijalankan.

\section{Metode Penelitian}

\section{Tempat dan Waktu Penelitian}

Penelitian ini dilakukan di Kabupaten Karo. Pemilihan lokasi penelitian dilakukan secara sengaja (purposive) karena lokasi penelitian merupakan salah satu sentra produksi usahatani sayuran Penelitian dilakukan selama 3 bulan, dari bulan september sampai bulan Desember 2018.

\section{Bentuk Penelitian}

Bentuk penelitian yang digunakan dalam penelitian ini adalah penelitian survei yang menggunakan data primer dan sekunder. Data primer berasal dari hasil wawancara langsung ke petani sayuran dengan menggunakan kuisioner yang telah dibuat sebelumnya. Data sekunder berasal dari literatur-literatur seperti buku, jurnal, tesis dan semua sumber literatur yang mendukung penelitian ini. Selain itu data sekunder juga berasal dari data Badan Pusat Statistik Sumatera Utara dan kantor pemerintahan terkait.

\section{Populasi dan Sampel}

Populasi merupakan keseluruhan objek yang diteliti di atas, baik yang terbatas maupun yang tidak terbatas. Berdasarkan data dari BPS Kabupaten Karo (2018) populasi dalam penelitian ini adalah jumlah keseluruhan petani sayuran yang ada di kabupaten Karo yang berjumlah 184.000 orang.

\section{Teknik Pengumpulan Data}

Menurut Lubis (2009) pengumpulan data adalah pencatatan peristiwa-peristiwa atau hal-hal atau keterangan-keterangan atau karakteristik-karakteristik sebagian atau seluruh elemen populasi yang akan menunjang atau mendukung penelitian. Data primer dikumpulkan dari responden dengan menggunakan teknik observasi langsung. Alat pengumpulan data yang digunakan berupa daftar pertanyaan melalui kuesioner 


\section{A. Metode Analisis Data}

\section{Analisis Linier Berganda}

Untuk menjawab masalah pertama, teknik analisis yang digunakan adalah dengan menggunakan regresi linier berganda. Analisis ini bertujuan untuk mengaitkan dua atau lebih variabel yaitu, antara pendapatan dengan faktor biaya produksi dengan rumus sebagai berikut :

$$
\mathrm{Y}=\mathrm{bo}+\mathrm{b} 1 \mathrm{X} 1+\mathrm{b} 2 \mathrm{X} 2+\mathrm{b3} \mathrm{X3}+\mathrm{b} 4 \mathrm{X}_{4}+\mathrm{b} 5 \mathrm{X} 5+\mathrm{b} 6 \mathrm{X} 6+\mathrm{b}_{7} \mathrm{X}_{7}+\mathrm{b} 8 \mathrm{X} 8+\ldots \ldots \ldots . . . \mu(3.1)
$$

$$
\begin{array}{ll}
\text { Dimana }: & \mathrm{Y}=\text { Pendapatan } \\
& \text { bo }=\text { Intercep } \\
& \mathrm{X}_{1}=\text { pupuk } \\
\mathrm{X}_{2}=\text { pestisida } \\
\mathrm{X}_{3}=\text { harga } \\
\mathrm{X} 4=\text { tenaga kerja } \\
\mathrm{X} 5=\text { tingkat pendidikan } \\
\\
\text { b1, b2, b3, ... Koefisien Regresi }
\end{array}
$$

\section{Uji Penyimpangan Asumsi Klasik}

Untuk mendapatkan model persamaan regresi yang baik dan benar-benar mampu memberikan estimasi yang handal dan tidak biasa, maka perlu dilakukan uji terhadap penyimpangan asumsi klasik yang meliputi normalitas, heteroskedastisitas, multikolineieritas. Sedangkan asumsi autokeralasi tidak dilakukan karena data penelitian ini bukan data time-series.

\section{Normalitas}

Sunyoto (2011) mengatakan uji normalitas bertujuan untuk menguji data variabel bebas $(\mathrm{X})$ dan data variabel terikat $(\mathrm{Y})$ pada persamaan regresi yang dihasilkan apakah berdistribusi normal atau berdistribusi tidak normal. Persamaan regresi dikatakan baik jika mempunyai data variabel bebas dan terikat berdistribusi mendekati normal atau normal sama sekali. Selanjutnya Lubis (2009), mengatakan bahwa ciri-ciri dari seberan normal adalah simetris, maka semua ukuran pemusatannya (mean, median, modus, midrange) berada pada satu titik.

\section{Heteroskedastisitas}

Uji heteroskedastisitas bertujuan untuk menguji apakah dalam model regresi terjadi ketidaksamaan variance dari residual satu pengamatan ke pengamatan yang lain. Selanjutnya Sunyoto (2011), mengatakan jika resi residualnya mempunyai varians yang sama disebut homoskedastisitas dan jika variannya tidak sama/berbeda disebut heteroskedatisitas. Persamaan regresi yang baik adalah jika tidak terjadi heteroskedastisitas.

\section{Multikolinieritas}


Uji multikolinieritas berfungsi untuk menguji apakah pada model regresi ditemukan adanya suatu hubungan linier yang sempurna (mendekati sempurna) antara beberapa atau semua variabel bebasnya. Menurut Sunyoto ( 2011), untuk mengukur tingkat asosiasi (keeratan) hubungan/pengaruh antar variabel bebas tersebut melalui besaran koefisien korelasi (r). Dikatakan terjadi multikolinieritas jika koefisien korelasi antara variabel bebas (X1 dan X2, X2 dan X3, dan seterusnya) lebih besar dari 0,60. Dikatakan tidak terjadi multikolinieritas jika koefisien korelasi antara variabel bebas lebih kecil atau sama dengan 0.60 ( $\mathrm{r} \leq 0.60)$. Sedangkan menurut Gujarati (2003), untuk mendeteksi ada atau tidaknya multikolinieritas dalam regresi dilakukan dengan melihat nilai VIF ( Variance Inflation Factor). Jika nilai VIF lebih besar dari 10, dalam data terdapat multikolinieritas yang sangat tinggi.

\section{Koefisien determinasi $\left(\mathbf{R}^{2}\right)$}

Budiarto (2002) Pengujian koefisien determinasi $\left(\mathrm{R}^{2}\right)$ digunakan untuk mengukur kekuatan hubungan antara variabel independent.

\section{Pengujian Parameter secara keseluruhan (uji-F)}

Tujuan pengujian ini adalah untuk melihat apakah variabel bebas yang digunakan secara bersama-sama berpengaruh nyata pada variabel tak bebas atau apakah signifikan atau tidak model dugaan yang digunakan untuk menduga pendapatan sawit.

\section{Pengujian Parameter secara Individu (Uji-t)}

Tujuan pengujian ini adalah untuk mengetahui apakah dari masing-masing variabel bebas (Xi) yang dipakai secara terpisah berpengaruh nyata atau tidak terhadap variabel tidak bebas (Y). Pengujian secara statistik adalah sebagai berikut

Hipotesis :

H0 : bi = 0 Hipotesis nol (Ho) yang akan diuji adalah suatu parameter (bi) sama dengan nol, artinya, suatu variabel independen bukan merupakan penjelas yang signifikan terhadap variabel dependen.

$\mathrm{H} 1: \mathrm{bi} \neq 0$ Hipotesis alternatif $(\mathrm{H} 1)$ yang akan diuji adalah suatu parameter tidak sama dengan nol, artinya, variabel independennya merupakan penjelas yang signifikan terhadap variabel dependen.

\section{Analisis Pendapatan}

Penerimaan merupakan hasil kali besarnya jumlah sawit yang diproduksi dengan harga jual. Untuk menganalisa pendapatan petani sawit digunakan persamaan Soekartawi (1995). Dimana penerimaan usaha adalah perkalian antara produksi yang diperoleh dengan harga jual

\section{ANALISIS PENDAPATAN}

Tingkat keuntungan dan kontribusi usahatani sayuran terhadap pendapatan keluarga dari hasil penelitian yang dilaksanakan di Kabupaten karo diketahui rata-rata produksi petani sayuran sebesar $8900 \mathrm{Kg}$ dalam setahun /ha dan ini berarti penerimaan rata-rata setiap petani per tahun sebesar Rp 71.200.000, dengan harga jual Rata rata $\mathrm{Rp} 8000 / \mathrm{Kg}$, atau sebesar Rp 6.000.000/bulan. 


\section{Kontribusi Pendapatan Petani Sayuran Terhadap Total Pendapatan Keluarga}

Pendapatan keluarga petani adalah pendapatan yang diperoleh dari kegiatan usahatani ditambah dengan pendapatan rumah tangga yang berasal dari luar usahatani dan luar pertanian. Sumber pendapatan utama keluarga di daerah penelitian adalah dari usahatani sayuran, yang juga berkontribusi paling besar terhadap pendapatan keluarga. Dan sumber pendapatan keluarga petani dari usahatani luar sayurant seperti padi, jagung, coklat, karet, pisang merupakan usahatani sampingan yang memberikan pendapatan tambahan pendapatan keluarga yang produksinya dihitung berapa kali musim dalam satu tahun. Sedangkan sumber pendapatan keluarga dari usaha luar pertanian adalah bersumber dari tenaga mengajar (guru), berdagang, jasa pengangkutan, buruh bangunan, menjahit. Gajian ataupun upahan yang dalam hal ini pendapatan tersebut dihitung dari pendapataan per bulannya.

Besarnya kontribusi pendapatan petani pada usahatani sayuran terhadap pendapatan keluarga petani contoh adalah sebesar Rp. 71.200.000 per tahun atau sebesar 80,72 persen, sedangkan sumbangan pendapatan petani dari usaha lain adalah sebesar Rp.15.000.000 per tahun atau sebesar 17,01 persen dan sumbangan pendapatan luar usahatani sebesar Rp.2.000.000 atau sebesar 2,27 persen.

Dari hasil analisis tersebut dapat diketahui bahwa usahatani sayuran yang dilakukan oleh petani di Kabupaten Karo menguntungkan dan layak untuk dijalankan. Semakin besar keuntungan yang diperoleh dalam berusahatani hal ini akan mendorong/memotivasi petani untuk melakukan kegiatan usahatani tersebut.

\section{Kesimpulan dan Saran}

Kesimpulan :

1. Usahatani sayuran mempengaruhi tingkat pendapatan petani sebesar $80.72 \%$

2. Usahatani secara ekonomis didaerah penelitian menguntungkan dengan rata rata $\mathrm{R} / \mathrm{C}$ ratio perpetani perhektar sebesar 2,54

3. Usaha tani dilokasi penelitian layak untuk dijalankankarena penghasilan petani perbulan sebesar Rp 6.000.000/bulan jauhdari upah mininum Propinsi

Saran :

1. Petani sebaiknya tetap menggunakan bibit sayuran yang berkualitas agar produksi semakin baik.

2. Petani harus aktif dalam mencari informasi tentang perkembangan teknologi pertanianserta aktif dalam mencari informasi pasar, agar harga yang mereka peroleh tinggi.

\section{DAFTAR PUSTAKA}

Akhirmen. (2006). Statistik II. Padang: Universitas Negeri Padang.

Arikunto, Suharmisi. (2006). Prosedur Suatu Penelitian Suatu Pengantar Praktek. Jakarta: Reanika Cipta.

BPS Kabupaten Karo dalam angka (2017)

Daniel, Muchtar. (2002). Pengantar Ekonomi Pertanian. Jakarta : Bumi Aksara 
Deswanda, Dedy. (2009). Faktor - Faktor yang Mempengaruhi Pendapatan Petani Kelapa Sawit. Padang. Universitas Negeri Padang.

Firdaus, Muhammad. (2010). Manajemen Agribisnis. Jakarta. Bumi Aksara.

Husni, Fitratul. (2009). Faktor - faktor yang Mempengaruhi Produksi Padi Sawah di Kecamatan Baso Kabupaten Agam).

Rizal, K. (2016). Faktor sosial ekonomi yang mempengaruhi tingkat pendapatan petani kelapa sawit di Kecamatan Rantau selatan Kabupaten LabuhanbatuSumatera utara. 